\title{
The Oversight Committees in Developing Countries - Public Financial Control and the Expectations Gap - Some Empirical Evidence from Sri Lanka
}

\author{
Prem Yapa \\ School of Accounting, RMIT University, Australia \\ E-mail: prem.yapa@rmit.edu.au
}

Received: Oct. 11, 2012 Accepted: March 4, $2014 \quad$ Published: June 1, 2014

doi:10.5296/ajfa.v6i1.2523 URL: http://dx.doi.org/10.5296/ajfa.v6i1.2523

\begin{abstract}
This paper examines whether it is possible to implement an effective financial control through public oversight committees and establish public sector accountability and transparency as expected by the general public in Sri Lanka. The time is ripe for a debate on whether the public sector governance in Sri Lanka is socially well placed to safeguard the general public over the last few decades. Interviews with key stakeholders are analyzed using stakeholder theory. Findings reveal that despite the summons were sent to some public institutions, they did not appear before oversight committees. The standing orders specify that any person or document can be summoned before an oversight committee, yet parliamentarians are not summoned before oversight committees under any circumstances. The public officers responsible for fraudulent acts are transferred or retired before the completion of hearings of oversight committees. A little attention is paid on the best practice of parliamentary scrutiny and its impacts on the public accountability. There had been a civil war in Sri Lanka over the last three decades. Debate on the defence expenditure continues. This issue has to be further investigated in a future study.
\end{abstract}

Keywords: Sri Lanka, Oversight committees, Public sector, Financial control 


\section{Introduction}

Over the last few decades the research has shown that parliamentary governments have used committees to achieve effective performance of their legislative responsibilities (McGee, 2002; Loney, 2004; Victoria, 2000; World Bank, 2006). Sri Lanka, as a democratically elected government, exercises oversight function in the financial performance of public institutions through Committee on Public Accounts (COPA) and the Committee on Public Enterprises (COPE). These committees allow the people to participate through written submissions and to appear before public hearings (by invitation) to canvass issues of concern. The committees report to the legislature on the use of public funds and other matters. They can have a major influence on revealing inefficiency or misuse of funds and in recommending improvements to policy, legislation and administration. The accounts of government organisations are audited by the Auditor-General and form the basis of the investigations of COPA and COPE.

The COPA (formally named as Public Accounts Committee) is the oldest oversight committee in Sri Lanka. This committee's task is to probe the managerial efficiency and financial discipline of the Government, its Ministries, Departments, Provincial Councils and Local Authorities. In doing so, the COPA is to examine the sums voted by Parliament along with the report of the Auditor-General. During the course of its deliberations, the Committee obtains evidence from the Secretaries to the respective Ministries, who are the Chief Accounting Officers (CAO), Heads of Departments and other responsible officers. The Committee also regularly summons Directors-General of Public Finance, State Accounts and National Budget or their nominated representatives. It is the duty of the CAOs to personally appear before the Committee to explain and justify the financial activities of the Departments under the purview of their Ministries. The recommendations of the Committee may contain directives to Government Departments and Ministries and such directives are deemed to be those of Parliament. Copies of Committee reports are distributed among Officers of the Ministries, Departments, Provincial Councils and Local Authorities.

The second oversight committee (i.e. COPE) has been established to ensure the observance of financial discipline in Public Corporations and other Semi Governmental bodies in which the Government has a financial stake. The COPE is to report to Parliament on accounts examined, budgets and estimates, financial procedures, performance and management of corporations and other government business undertakings. It has the power to summon the relevant officials and such other people as it thinks fit to obtain evidence and call for documents.

Both oversight committees report to the Parliament and the recommendations contained in their reports are deemed to be directives to the respective Corporations or Statutory Boards for compliance. The recommendations of the Committee may contain directives to Government Departments and Ministries and such directives are deemed to be those of Parliament. Copies of Committee reports are distributed among Officers of the Ministries, Departments, Provincial Councils and Local Authorities (Warnapala, 2004; Ceylon Daily News, 8, October, 2008). 
The term 'expectations' could provide various connotations that, although similar, have meanings that are not identical. In an accountability framework these may include a perception of what users or general public believe as 'should be' the role of oversight functions and what users think 'will happen or realistically expect' of the provision of audit services. Both are in turn influenced by a concept of the 'ideal' type of audit service. There have been a number of studies concerned with the public expectations by oversight authorities or auditors and what the profession believes their responsibilities to be (Nagy, 2000).

This paper raises a broad question that is whether it is possible to implement an effective financial control through public oversight committees and establish public sector accountability and transparency as expected by the general public in the Democratic Socialist Republic of Sri Lanka. In order to perform a more enlightened analysis on this question, a few sub questions are formed as follows: 1 . Do the oversight committees have power to summon persons and documents? 2. Do oversight committees have sufficient power to summon officers? 3. What documents are summoned before the oversight committee? 4. Do oversight committees allocate sufficient time for hearings? 5. What roles does Auditor General play? This paper aims to explain the public accountability in Sri Lanka. Furthermore, the authors strongly feel that the time is ripe for a debate on whether the public sector governance in Sri Lanka is socially well placed with regard to safeguard the general public over the last few decades. This is the motivation for this study.

\section{Methodology}

Primary data for this paper was gathered from two sources. Firstly, semi-structured interviews were conducted with senior public officers to gain insights into oversight committee practices. The interviewees consisted of COPA and COPE committee membership, senior officers from the Ministry of Finance and the Treasury Department in Sri Lanka. Secondly, similar interviews were conducted with some parliamentarians on the oversight aspect in the public sector. These respondents expressed their comments and opinions based on their experiences and present positions in their respective departments or ministries. In total twenty five interviews were conducted and five meetings attended to collect primary data for this study. Some parliamentarians also agreed to take part in interviews. For most interviews, our records consisted primarily of notes taken during the meetings and additional notes were written up immediately following the meetings. Fifteen interviews were taped and transcribed. In the other instances, notes taken during the face to face meetings and more extensive write ups immediately following interviews were used. These notes were confirmed with participants for validity. Typically, interviewees were visited on more than one occasion. This approach enabled a rapport to build up and also made it possible to confirm points from earlier meetings, or clarify some issues relating to the practice of the oversight committees. Some of these points also related to the authentication of textual materials relating to committees. Based on the importance of the two committees, which is in the forefront of ensuring fair play in matters pertaining to utilising public funds on Government and Semi Government Institutions, following sections explain the role and the functions and the authority to summon persons and documents to COPA and COPE. 
The remainder of the paper is organised as follows. Section 3 builds and draws the theoretical framework to explore the historical background of the oversight committees and its development. 4 explain the role and the operations of the Committee on Public Accounts. Section 5 explains the role and the operations of Committee on Public Enterprises. Using interview data and documentary records, the authority to summon persons and documents to oversight committees is explained in Section 6. The final section provides findings, a discussion and concludes the paper with some topics for further research.

\section{Stakeholder Theory and Public Sector Resource Management Strategies}

Stakeholder Theory has given valuable insight on firm accountability towards the Stakeholder. Theory was enlightened by Freeman (1984) through his innovative work. He discussed important elements on firm responsibility towards the stakeholder, "any group or individual who can affect or is affected by the achievement of the organisation objectives" (Freeman, 1984). In the recent debate of corporate governance and public sector governance, the stakeholder literature has used to broaden the domain beyond the shareholder interest to more boarder perspective of stakeholder to states by taking the idea of non-shareholder stakeholder statute (Even \& Freeman 1988; Selznick, 1957), also known as other constituency statues to explain the accountability of the organisations to public at large (Donaldson \& Preston, 1995; Even \& Freeman, 1995). Moreover, studies have been conducted, taking the conceptual context of stakeholder literature, to explain the public sector fund management and administration (Tennert \& Schroeder, 1999; Lisa, et al. 2005; Hans, 2000; Meijer, 2006). However, there are opponent view points from the prominent proponents of the theory.

Scholl has studied on the formation of Joint Project Team to expand the scope of the State sector, Central Accounting System (CAS) of the New York State Government. He has described applicability of stakeholder theory to the public sector and accepted the capacity of the theory, to discuss the public sector performance (Scholl, 2000). Thus, this paper built a relationship between firm which we assume that represent public sector organizations such as (government organisations including parliament members) and its accountability towards the stakeholder which we assume that represent (nation's stake through the oversight committees). We used the, Mitchell et al.'s “concept of stakeholder identification typology” which they suggest as a dynamic model (Mitchell, 1997).

Thus, the study intended to critically analyse the following three aspects.

1. The stakeholders (Oversight committees which represent the general public through parliament) power to influence the firm (all public organisations).

2. Legitimacy of the stakeholder's (Oversight Committee's, which represent the general public through parliament) relationship with the firm (all public sector organisations) and

3. The urgency of the stakeholder's (Oversight Committee's, which represent the general public through parliament) claim on the firm (all public sector organisations). 
"The broad view of the stakeholders, in contrast, is based on the empirical reality (Mitchell, 1997)”. Thus, this study has explored the empirical evidence through our study.

\section{The Committee on Public Accounts (COPA) or Public Accounts Committee (PAC)}

As revealed in many studies there are evidence that powerful legislatures can undermine fiscal discipline, which highlights a possible dilemma for legislative strengthening work (Wehner, 2003). There seems to be many historical examples of governments that have fallen because the people felt that the government was not acting or protecting in the interest of people. The stability of government relies basically on good governance and effective parliamentary scrutiny and felt interests of the people through various committees (Saward, 1996). The capacity of Public Accounts Committees to be instrumental in achieving high standards of ethical governance through holding governments to account has been overlooked for decades. It is important to gain the assistance of civil society, aid institutions, international financial agencies, and others who have an interest in honest stable government, the eradication of corruption and strong democratic institutions to overcome the 'governance gap’ (Loney,2004).

The PAC in Sri Lanka has a historical significance as an institution of parliamentary control similar to that in countries where Westminster model of parliamentary government is practiced. In these countries the PAC derives inspirations from the tradition and experience of the PAC of the House of Commons in the United Kingdom.

The parliamentary institutions in Sri Lanka began to develop with the introduction of the Legislative Council in 1833 under the recommendations made by the British government under the leadership of Colebrooke and Cameron ${ }^{1}$. The establishment of Legislative Council is a land mark in the development of the Ceylon Constitution and the eventual evolution of democratic parliamentary government in Sri Lanka. This council had to be consulted in most administrative matters than financial. Subsequently, the Council was able to obtain more financial control in 1839, 1867 and 1903 (Pakeman, 1970; Silva, 1973; Warnapala 2004). Along with these developments, in 1907, the Finance Committee was introduced and in 1915 the Finance Committee was given the power to examine the annual estimates before they were presented for the first reading in the Council. During the period from 1918 to 1925 a series of legislative reforms were taken place in Sri Lanka (Pakeman, 1970). The Standing Committee of Public Accounts was set up on 5 September 1923 as a result of the motion, which was placed before the Legislative Council in October 1921. The Constitution of 1924, converted the Finance Committee into a consultative body acceptable to the majority in the Council. The number of committees increased and in 1926 there were 80 committees and commissions including Public Accounts Committee (Warnapala, 2004).

\footnotetext{
${ }^{1}$. George Colebrooke, who had experience in Colonial Administration in India and Java, visited Ceylon in 1829 as a Commissioner to inquire into the state of the island's finance and administration. He was followed a years later by a legal colleague from Scottish bar, Charles Hay Cameron, whose function was to probe the judicial administration. There recommendations published in 1832 in four reports by Colebrook on the Administration of the government, on Revenue, on Compulsory Service, and on Establishment, and one report by Cameron on Judicial Establishment, were of profound value, for their subsequent implementation began a long drawn-out process which resulted ultimately in the independence of Ceylon within the Commonwealth.
} 
The new Constitution recommended by the Donoughmore Commission ${ }^{2}$ (1931-47) allowed Ceylon to perform both legislative and executive functions. Then the Donoughmore Constitution was brought in to being by an Order in Legislative Council in 1931. The uni cameral legislature which was established under this Constitution, the State Council was entrusted with a dual function: it sat in executive as well as legislative (Pakeman, 1970; Ludowyk, 1966, Warnapala, 2002).

The PAC has been set up under the Standing Order No. 125 of the Parliament of the Democratic Socialist Republic of Sri Lanka. The main purpose of the Standing Orders is to prescribe the procedure for the functioning of Parliament in an orderly and meaningful manner. The duty of the PAC is to examine the accounts showing the appropriation of the sums granted by the parliament to meet the public expenditure and such other accounts laid before parliament with the reports of the Auditor General. According to Standing Order No.125 of Parliament, the PAC has the power to summon any person before the committee hearings and examine any records or documents. The Standing Order 125 outlines the following items:

(1) there shall be a committee to be designated the committee on Public Accounts, nominated by the Committee on Selection. (2) it shall be the duty of the Committee to examine the accounts showing the appropriation of the sums granted by Parliament to meet the public expenditure and such other accounts laid before Parliament as the Committee may think fit, along with the reports of the Auditor General on local authorities. (3) the Committee shall, from time to time, report to parliament on the accounts examined, the finances, financial procedures, performance and management generally of any department, local authority and on any matter arising there from. (4) The Committee may when it considers necessary appoint sub-committees of its own members to examine and report to the Committee on all accounts and the finances and management of such departments, local authorities as the committee may direct. (5) the Committee or any of its subcommittees shall for the performance of its duties have the power to summon before it and question any person and call for and examine any paper, book, record or other document and to have access to stores and property. (6) the quorum of the Committee shall be four members. (as amended February 26,1993 - Published by the Parliament Secretariat, Colombo, Sri Lanka).

The PAC's main task is to investigate the managerial efficiency and financial discipline of the Government, its Ministries, Departments, Provincial Councils and Local Authorities. In 1972, the Constitution of Sri Lanka was changed and the name of the Legislature - House of Representatives was changed to National State Assembly. It was adopted with a unicameral (single chamber) legislature. This republican constitution introduced a highly centralised system of government with a strong executive and a constitutional head of state. The committees established under earlier Constitution continued to function under the new Constitution. (Wijesekara, 2002; Warnapala, 2004). The Republic Constitution of 1972 was

\footnotetext{
2 The Commission (consist of four Commissioners) under the chairmanship of the Earl of Donoughmore appointed to examine the working of the 1924 Constitution and to consider any proposal for its revision. They presented their report to the Secretary to the State in July 1928.
} 
replaced by the Constitution of 1978 and it brought in a Presidential System cum Parliamentary system of Government in Sri Lanka. The Constitution of 1978 retained the unicameral legislature and elected executive president with an enormous plenitude of power. The constitution combines the basic features of the Westminster Parliamentary system with the executive Presidential System. This constitution introduced proportional representation in the system of election. It resulted in greater diversity of representation with a higher likelihood of minority or coalition of government being formed (Wijesekara, 2002; Warnapala 2004). Like other democratic governments, functions of the Sri Lankan Parliament are law making, scrutiny of the executive, ventilation of public grievances and the control of public finance (Wijesekara, 2002). The 1978 Constitution introduced several changes in the structure of the Committees and five more new Committees were added including the second oversight committee - COPE. The Constitution of the Democratic Socialist Republic of Sri Lanka, in its Article 148 states as follows:

'Parliament shall have full control over public finance. No tax, rate or any other levy shall be imposed by any local authority or any other public authority, except by or under the authority of a law passed by Parliament or of any existing law'

Therefore, even though the government and the Treasury prepare the annual budget, its proposals cannot be implemented without the parliamentary approval. The annual budget includes all government expenditure for the coming financial year as well as the proposals for taxation and other revenue measures. The budget expenditure is set out in detail in the Appropriation Bill (PAC, Parliament Secretariat, 2006).

According to Financial Regulations of the government of Sri Lanka, it is the duty of the Minister of Finance to appoint each Secretary to a Ministry to be 'the Chief Accounting Officer (CAO) of his Ministry and delegates to him the responsibility for supervising departmental financial transactions, subject to the direction of the Treasury (Financial Regulations of the Government of Sri Lanka, 1992,p.45). According to this arrangement, the Treasury retained the general control over government financial matters while the CAO discharged his constitutional responsibility of supervision over the departments concerned in respect of their financial transactions. In the same manner, a Head of Department was made the Accounting Officer in respect of all financial transactions of his department, and he is individually responsible to the CAO (Warnapala, 2004,p.118).

The tasks of the COPA or PAC are as follows:

1. To probe whether the allocated funds have been used by the respective ministries, Departments, Local Authorities etc with the maximum efficiency and whether the financial regulations have been duly complied with.

2. If any excess has taken place to find out whether it was done with proper authority and whether they can be justified. If over expenditure is justifiable the Committee can make suitable recommendations to Parliament to allow the same.

3. If excess cannot be justified to make recommendations regarding action to be taken to prevent such occurrences in future. 
4. The committee can also make recommendations relating to underutilization of funds as well as over expenditure on extravagance (PAC, Parliament Secretariat, 2006).

It is interesting to note that the reports of COPA are usually not debated in Parliament though they may sometimes be referred to in the course of other debates. However, recommendations contained in such reports are considered to be directions to the Parliament (PAC, Parliament Secretariat, 2006). Next section explains the role of COPE - the second oversight committee to monitor State Corporations and business Undertakings in Sri Lanka.

\section{The Committee on Public Enterprises (COPE)}

The duty of the COPE is to report to the Parliament on accounts examined, budgets and estimates, financial procedures, performance and management of corporations and other government business undertakings. The accounts of these organisations are audited by the Auditor-General and form the basis of the investigations of the Committee. The COPE has the power to summon persons and documents before the examination purposes under the Standing Order 126 of Parliament of Sri Lanka. The Standing Order 126 explains the authority as follows:

(1) There shall be a Committee to be designated the Committee on Public Enterprises nominated by the Committee of Selection. (2) It shall be the duty of the Committee to examine the accounts of public corporations and of any business or other undertaking vested under any written law in the government laid before Parliament, along with the reports of the Auditor General thereon.

(3) The Committee shall, from time to time, report to parliament on the accounts examined, the budgets and annual estimates, the finances, financial procedures, performance and management generally of any public corporation or of any business or other undertaking vested under written law in the Government and on any matter arising there from. (4) The Committee may when it considers necessary appoint sub-committees of its own members to examine and report to the Committee on all accounts, the budgets and annual estimates, the finances and management of such public corporations or of any business or other undertaking vested under any written law in the government as the committee may direct. (5) The Committee or any of its sub-committees shall for the performance of its duties have the power to summon before it and question any person and call for and examine any paper, book, record or other document and to have access to stores and property. (6) The quorum of the Committee shall be four members.

The COPE has the power to summon the relevant officials and such other people as it thinks fit to obtain evidence and call for documents. The Committee reports to Parliament and the recommendations contained in their reports are deemed to be directives to the respective Corporations or Statutory Boards for compliance. For example, The COPE report (2007) revealed that the country has lost 600 million rupees (about 6 million US dollars) mainly due to malpractices of 20 State Enterprises. Among some of the institutions that financial malpractices took places are Foreign Employment Bureau, Sri Lanka Cashew Corporation, National Housing Development Authority, National Gem and Jewellery Authority, Exports 
Development Board and the Building Material Corporation, National Transport Commission, Associated Newspapers of Ceylon Ltd., Sri Lanka Rupavahini (TV) Corporation, Sri Lanka Broadcasting Corporation, the Consumer Affairs Authority and the Mahapola Higher Education Trust Fund (Sri Lanka -News Desk, 2007). Next Section explains about the authority to summon persons and documents to oversight committees in Sri Lanka.

\section{Use of authority to summon persons and documents to oversight committees}

In order to obtain an understanding and evidence of the practice of summoning procedure of oversight committees in Sri Lanka, interviews were conducted with some members of parliament, senior officers of the Ministry of Finance and Treasury Department and oversight committee members. The researchers attended meetings with parliamentarians and officials of the Ministry of Finance and the Treasury Department in Sri Lanka during the latter part of 2008 and 2010 to obtain evidence associated with the process of summoning persons and documents to oversight committees. In most interviews, respondents extended their full cooperation to this study and encouraged researchers to conduct many more work in this area in Sri Lanka as there is a dearth of research into parliamentary accountability. This section reports the outcome of interviews.

\subsection{Oversight committee hearing process}

Presently, there are about 300 public institutions in Sri Lanka. These public institutions are operated mainly with the public funds provided by the Sri Lankan government. Therefore, the operations of these public institutions are under the close scrutiny by oversight committees on a regular basis. In the oversight committee hearing process, apparently, all the public institutions are not being summoned before committees. As revealed by the former Auditor General and other respondents (Interview 22, 3, 4) in Sri Lanka, the summoning to oversight committees is happening in the following manner:

(a). The oversight committee secretariat prepares a list of public institutions that are to be summoned for investigations.

(b). The AG is also contacted by the oversight committee Secretariat to find his views on public institutions.

(c). Oversight committee members also suggest public institutions that are to be investigated. Practically, all the deliberations in the oversight committee are based on the AG's report.

There is no formal pattern or guideline to summon public institutions before the oversight committee. The public institutions are summoned based on a certain priority system adopted by the committee secretariat. The hearing committee consists of the Chairman, the Secretary to the committee, Director of Public Enterprises and his supporting staff - and the Auditor General and his supporting staff. The witnesses are summoned before the committee regularly for questioning (Interview 1). Basically the Secretariat sends summoning letters to Secretary of a Cabinet Ministry and he directs it to respective CAO of respective Ministries or Departments. The CAO has to prepare a report based on the 'Audit Paragraphs' of the AG. These reports are submitted to the secretariat normally one week before the committee 
hearing. However, some Ministries submit their reports on the same day as the committee proceedings are taking place.

At the hearing stage of the committee, the members of oversight committee are provided with minutes of the previous meeting, standing orders, audit queries raised by the AG and additional comments made by the AG with respect to previous audit queries and sometimes the newspaper cuttings (media news on matters relating to the public institution) associated with a respective public institution.

\subsection{Do the oversight committees have power to summon persons and documents?}

As revealed by the interviewees, the duty of the oversight committee is to examine the sums voted by Parliament along with the report of the Auditor-General. In the course of its deliberations, the Committee makes all the efforts to obtain relevant evidence from the Secretaries of respective Ministries, CAOs, Heads of Departments and other responsible Officers. Additionally, the Committee regularly summons the Directors-General of Public Finance, State Accounts and National Budget or their nominated representatives (Interview, 6, 7, 8 and 25). The oversight committees in Sri Lanka, has the authority (under Standing Orders, $125 \& 126$ ) to summon any person such as present staff of any public institution, previous staff (or retired officers of any public institution) and documents. It is interesting to note that the parliamentarians or cabinet ministers are practically not being summoned for questioning. However, sometimes cabinet ministers are summoned to the committee as observers depending on the interest of the committee. During their observation time, some cabinet ministers provide comments relating to specific issues raised by the committee members or witnesses (Interviews 12, 23 18, 20, 23 and 25).

The oversight committees can summon people from government ministries, departments, local authorities (such as City councils) and provincial councils. The summoning of these institutions is done by the COPA. The other public enterprises such as Central Bank, universities, public corporations are summoned by the COPE. It is interesting to note that Standing Order does not say anything about State Owned Companies (SOC) hence SOCs are not monitored under COPE supervision.

Presently there are about 300 Ministries and Departments and about 325 local authorities and 8 provincial councils operating in Sri Lanka. The COPA meets about 40 to 50 times a year. For a year generally 40 or 50 public institutions could be summoned before COPA. As revealed by the committee records, some public institutions have never been summoned. However, all the 8 provincial councils were summoned during the year 2007 as COPA realised that they are important for investigations.

\subsection{Do oversight committees have sufficient power to summon officers?}

Another interesting point raised at interviews was whether the oversight committees have sufficient power to summon persons. According to standing orders 125 and 126, the committees have the full authority to summon respondents (public officers) before the committee. For example, during the past years, oversight committees have summoned only selected institutions. Some institutions have not been called upon by the committees 
(Interview 2, 10, 9). As indicated in records, in 1993, the committee heard evidence from seven CAOs and twelve accounting officers. In 1995, the committee heard evidence from 13 CAOs and 60 accounting officers and in 1996, the committee heard 16 CAOs and 21 accounting officers (Warnapala, 2004 p.123). As indicated by respondents to this study, over the past few years, nearly 150 CAOs and other officers have been summoned before the committees for various inquiries. The oversight committees have summoned following categories of individuals for hearings:

- $\quad$ The officials of Government Departments,

- $\quad$ Ministry officials,

- $\quad$ Treasury Officers,

- $\quad$ Chairmen and the Board of Directors of the Public Enterprises and Government Own Business Undertakings (GOBU),

- $\quad$ Interest Groups,

- $\quad$ Ex-Officials,

- $\quad$ Ex- Chairmen

- $\quad$ Board of Directors of the Public Enterprises and GOBU.

It clearly indicates that the oversight committees have the full authority summon any public officer before the committees and examine the accounts and accounting procedures that have been followed with the assistance of the Auditor General, the Directors of the Department of Public Finance, State Accounts and National Finance. The CAOs assisted by other relevant officers who explain and justify the finance activities and procedures of the Departments for which they are responsible.

As revealed by an interviewee,

'Some institutions are not summoned by oversight committees due to complications involved with regard to their nature of ownership. For example, Mihin $\mathrm{Air}^{3}$ and Lanka Transformers Limited $^{4}$ are operated as private institutions. However, when government offer tenders for

\footnotetext{
${ }^{3}$ Recently established local airline with the support of the government.

${ }^{4}$ Lanka Transformers Limited (LTL) was established in 1982, set up initially to produce Distribution Transformers to meet the local requirement. LTL, over the years has blossomed into the largest engineering organization within the Power Sector in Sri Lanka with an annual turnover exceeding SLR. 5.4 billion (US\$ 54 million).In addition to manufacturing of transformers for local and international markets, LTL has diversified into Hot dip Galvanizing, Power Generation, Fabrication of Steel Structures including lattice steel towers for power transmission and telecommunication systems, Turnkey Construction of Projects, Project Management, Energy Management, Information Technology, Broadband Networking, and a host of many engineering services. The significant factors in the LTL success story are the technical co-operation agreement with ABB AS of Norway and
} 
various businesses, these institutions are considered as public sector companies. So there is some confusion as to whether these institutions are belonging to public or private sectors. Direct political influence is involved in the summoning of such institutions to oversight committees. However, after a long debate on these matters in the parliament, Mihin Air was summoned by the oversight committee and in the hearing process the brother of the President of Sri Lanka influenced in many ways the witnesses. These are direct political interferences to protect the interest of the ruling political party. The other important issue is that majority of the members of oversight committees are from the ruling political party. Very few members represent the opposition parties in oversight committees. It is important to amend the appointment of members to oversight committees. Another important factor is that at the moment the oversight committees do not have the power to take appropriate legal actions against corrupt persons and institutions” (Interview - 16).

Another interviewee (interview 24) mentioned that the oversight committees have the power to summon any body before the committees. However, parliamentary ministers are not summoned as witnesses. According to him the chairperson of the committee is appointed from the ruling party and he was appointed recently as the chairperson of COPE with the majority support from the parliament. The government expects a chairperson from the ruling political party mainly to avoid unwanted troubles. It is important to note here that oversight committees are functioning as parliamentary device of control. However the committee confines itself to those points raised by the Auditor General in his reports. The committee has the full power to question the persons summoned before the committee on any matter related to accounts under scrutiny by the committee.

\subsection{What documents are summoned before the oversight committee?}

As revealed by some interviewees (Interviews 2, 5, 8, 11, 13, 14, 15), the oversight committees have the power to summon documents to the hearing process as evidence. In the past, many documents have been summoned for investigation purposes. The documents tabled in the committee normally fall into five categories:

(1) Annual reports,

(2) Report of the Auditor General,

(3) Comments on the report of the Auditor General prepared by the particular Public Enterprise,

(4) A profile prepared the Department of Public Enterprises on the particular public enterprise ,

(5) Strategic plans prepared by various public institutions.

the Company's well-trained engineers numbering over 60 and the competent staff. The Company employs around 800 personnel directly and indirectly. 
The examinations are conducted primarily on the basis of above documents that provide the most important guidelines for the committee and its members. However, various other documents are also summoned depending on the nature of the investigation carried out by the committee. There have been some instances where licensing documents, deeds, and contractual agreements of the related parties and letters of appointments of various public officers have been summoned for authentication and verification purposes (Interview 17,25 \& 21).

Among the documents, the annual reports of ministries, departments, local authorities and corporations have been summoned from time to time to substantiate the evidence for the examinations of the committee. Basically, the annual report of a public enterprise, in addition to the usual preliminary information relating to the board of directors and the senior management, furnishes information on such important matters as the report of board of directors, income and expenditure account, balance sheet, notes of the income and expenditure, the tax computation, relevant sections from the report of the Auditor General and the board's observation on the report of the Auditor General. It is also a requirement that the annual report has to be published in all three languages ( i.e , Sinhalese, Tamil and in English) and submitted to Parliament to be tabled by the minister concerned (Warnapla, 2004 and Interview 25).

It was often revealed that the delay in submitting the report was partially due to the fact that it had to be published in three languages; this was a common excuse given by several organisations at the oversight committee hearings (Interview 25). As revealed by some interviewees the major deficiency is the inordinate delay in submitting such reports to committees.

\subsection{Do oversight committees allocate sufficient time for hearings?}

At present there is no proper time management in the committee hearing process. The committee investigations are conducted on the basis of representations made by the AG and General Treasury as well as experience of the committee chairman and members and the issues reported. Hence, there is no plan of priority for hearing. Mainly due to this weakness, there are instances where some areas which needs serious attention and examination being left without any examinations or investigations (Interview 19, 22, 24,18).

\section{Findings, Discussion and Conclusions}

This section of the paper highlights the findings and provides a conclusion and some recommendations based on the study. The study analysed the oversight functions on public sector performance in order to achieve democratic rights of the general public. Empirical data was analysed based on stakeholder theory which has been modified by Mitchell et al,'s as “identification typology” model. This model helped us to identify unique features of the Sri Lankan case (Mitchell et al,. 1997). According to Standing Order 125, the role of the COPA is to examine the accounts showing the appropriation of the sums granted by the Parliament to meet the public expenditure and such other accounts laid before the Parliament along with the AG's report. In this process the role of the AG is pivotal for 
important decisions by the oversight committees. The role of the AG is to assist the parliament (legislature) to oversee the accountability of the executive and the constitutional arm of the Legislature. Therefore, the AG is expected under Article 154 to audit all Government expenditure and report to Parliament within 10 months of the close of the financial year. Article 154 (6) reads as follows:

'The Auditor General shall within ten months after the close of each financial year and as and when he deems it is necessary report to Parliament on the performance and, discharge of his duties and functions under the Constitution'.

The major findings of this study are as follows: In terms of article 154 of the Constitution of the Democratic Socialist Republic of Sri Lanka, the AG has been given the power to audit of the accounts of the government departments, the office of the cabinet Ministers, the Judicial Service Commission, the Parliamentary Commissioner for Administration, Secretary General of Parliament and the Commissioner of Elections, Local Authorities and the Public Corporations and Business or other Undertakings, vested in the government under any written law. Thus the AG has a pivotal role to play in the oversight committee practices. The AG is also empowered to obtain assistance in the examination of any technical, professional or scientific problem relevant to the audit from any independent person or institution. These provisions imply that the mandate of the AG is beyond the conduct financial audit, non financial audit, value for money audit as well as environmental audits. With the recent reforms on the Audit Act, the AG is given more independence in financial and non financial matters. This indicates the nature of controls on public expenditure and the expectations of the stake holders as explained in the theory.

The Finance Act No. 38 of 1971 empowers the AG to examine, accounts and finances, property of public corporations, organisations, systems and procedures, compliance with laws, rules and regulations, economy and efficiency aspects, and any other matters the AG deemed necessary. These provisions relating to the public corporations give wider mandate to the AG (Finance Act No. 38 of 1971, Sri Lanka). In accordance with these provisions, the AG's report bears significant evidence on the use of public funding by various public institutions. The COPE is dealing with public corporations and government undertakings and it has the power to summon persons and documents before the examination purposes under the Standing Order 126 of Parliament of Sri Lanka. Therefore, each report of the AG is referred to the COPA or COPE for further examination and investigation. It reveals that the COPA or COPE is the only channel through which Parliament can directly examine the public institutions about their management of public funds. The Committee reports on the accounts examined, the finances, financial procedures and performance and management of all Government Ministries, Departments and Local Authorities (Interview 22). The Figure 1 shows the role of the COPA and the COPE. 


\section{Role of the Committee on Public Accounts and Committee on Public Enterprises}

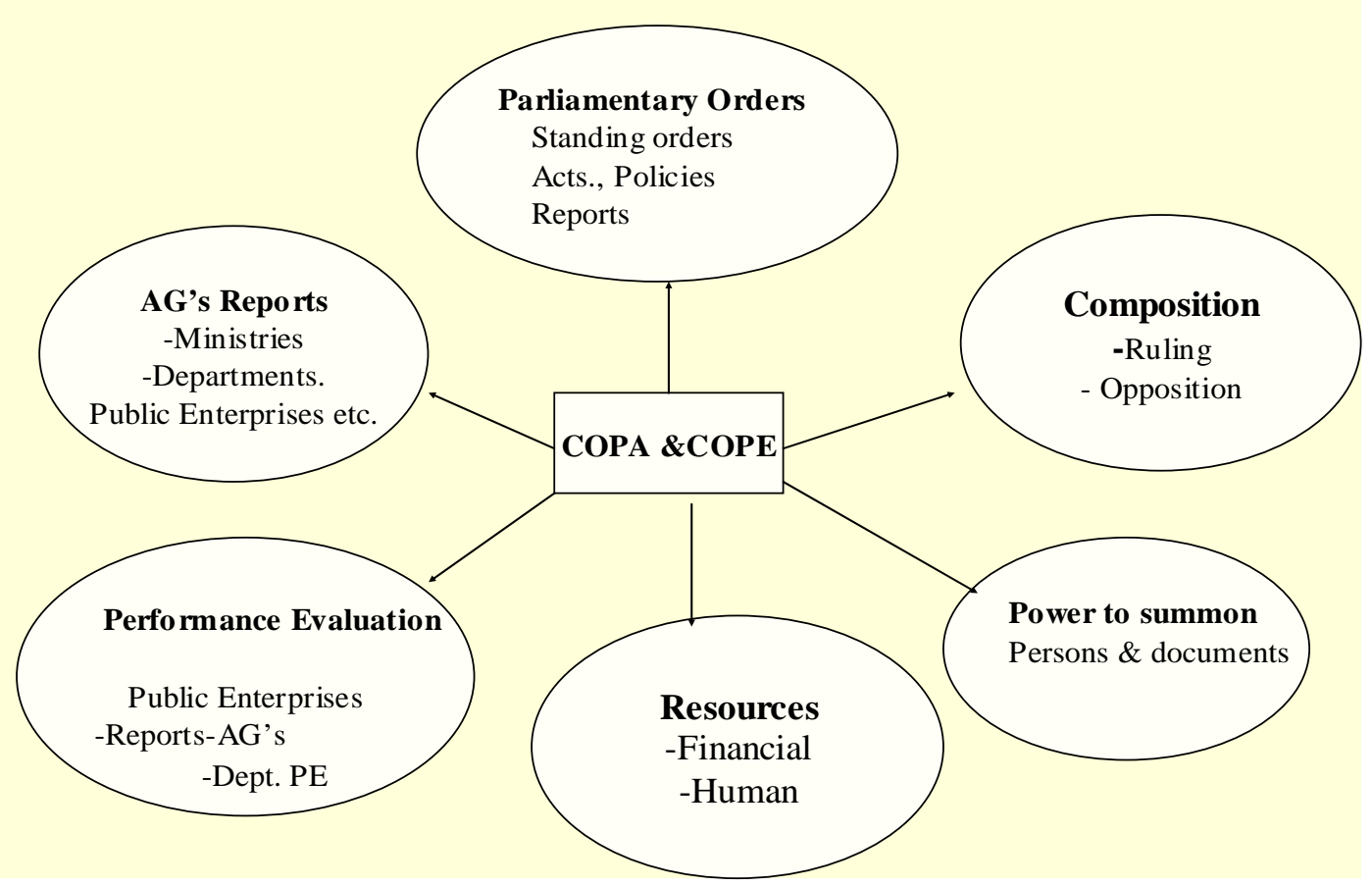

Figure 1. Role of the Committee on Public Accounts and Committee on Public Enterprises

As shown in Figure 1, COPA and COPE comprised of ruling party as well as opposition members, the AG and Directors of the Treasury. The COPA (Formally PAC) originally consisted of four members (Ceylon Sessional Papers 4, 1924). Subsequently, the membership of COPA increased to 7 in 1937 and again the membership was increased to ten in 1979. In 1993, again the membership was increased to 12 from year 1993 to 2001. In 2004, the membership was grown to 19 and in 2006 the number increased to 31 including the Chairperson. The committee quorum is four members. The increase in the membership took place basically to give equal opportunity to all elected political parties involved in the parliament. Given the inter-relationship of oversight committees and their composition from time to time, it is reasonable to assume as to how stakeholders are interested in the operations of the whole system. A unique feature in the committee is that a majority of the membership is vested with the ruling party. Presently, most members of oversight committees are comprised of Cabinet/ Non-Cabinet or Deputy Ministers of the government. Traditionally, an opposition member was appointed as the Chairperson of the COPA, a legacy inherited from the House of Commons. The appointment of the Chairman from the Opposition gives more confidence to the opposition. This tradition was maintained for three decades and appointment of a ruling party member as chairperson began after 1977 . The current practice is to appoint a chairman to the oversight committee from the ruling party. As mentioned by an interviewee, 
“.....my experience with 2007 and 2008 COPE proceedings indicated me that the chairperson for the committee should be appointed from the ruling party- because then the chairperson has a vigorous power to conduct the committee hearings...” (Interview 16).

At present the summoning of persons and documents to oversight committee seems to be not taking place according to a systematic manner - or as expected by the stake holder perspective. In an accountability framework (as explained in the stake holder perspective), the expectation of general public is to ensure a systematic approach to oversight functions and particularly to summon appropriate persons or institutions before the committees. As revealed by many interviewees, there is no approved methodology to determine public institutions that are to be summoned before committees. Basically the oversight committee chairperson and committee members decide which institution should be summoned based on available information with regard to a respective public institution. However, Auditor General's report and his recommendations is the basis for summoning public institutions for hearing process. The committee's examination of the accounts usually involves calling before it various officials of the departments who are questioned in regard to specific items contained in the AG's report.

It is important to appoint a permanent staff to the secretariat to assist committees for the identification of the public institutions that are to be summoned for investigations using a logical basis. And the institutions that are to be summoned must be identified at least 3 months before the scheduled date of summoning so that witnesses could get ready for the examination process with relevant documents. It is also important to maintain executive summaries of all the investigations performed by the committee for reference purposes and for subsequent examinations. As revealed by respondents this practice is absent in the current system.

In terms of provisions in Articles 154(4) (a) of the Constitution, the AG could obtain services of firms of qualified auditors in carrying out the audits of public enterprises, Estates and state banks. This indicates that the AG's Department does not have sufficient staff to carry out various audit examinations associated with the numbers of institutions involved in the scrutiny process. This is an important issue identified by most of the respondents to this study.

Despite the summons were sent to some public institutions, they did not appear before oversight committees. For example, Sri Lankan Airways, Telecom (Lanka) refused to give evidence or to appear before oversight committee indicating that they were not falling under the public sector category (interview 15,16 ). As revealed by respondents, apparently no legal action had been taken against them for refusing to appear before committees.

Even though standing orders specify that any person or document can be summoned before an oversight committee, as indicated, the parliamentarians are exceptional persons. The cabinet ministers or deputy ministers or ordinary members of parliament (presently only very few members of parliament with out cabinet or ministerial portfolio in the Sri Lanka parliament) cannot be summoned under any circumstances. 
Traditionally the COPA and COPE confine themselves to the issues raised in the AG's report. However, the involvement of State in economic and social development pave the way for high investment in the public sector and the increase in public expenditure and revenue made it difficult to have a effective control over public finance. The volume of work of the committee has increased enormously with the increase in public expenditure. Despite the growth of the public expenditure and revenue, increase in state agencies, the parliament in Sri Lanka has not been supplied with adequate information, development in information technology etc. Therefore, the question arose as to the adequacy of traditional methods of control adopted by PAC.

Due to inherent weaknesses in the Committee system, many public officers who appear before the oversight committees have not taken any seriousness of the committee hearing process. The public officers responsible for fraudulent acts are transferred or retired before the completion of hearings of oversight committees. Moreover, the follow-up actions on deliberations at the committee meetings of prior years appeared to be intentionally ignored. Thus, a little attention is paid on the best practice of parliamentary scrutiny and how it impacts the public accountability in Sri Lanka. As a result of country financial assessment exercise conducted by the World Bank in the recent past, the Bank has granted US \$ 494,000 financial assistance package to strengthen and enhance capacity of the two oversight committees - COPA and COPE. The financial assistance which came as a donor package is to be utilised to enhance capacity of the two committees with regard to obtaining documents $\backslash$ relevant material, interactive workshops, train manpower and obtain advice and the conduct of awareness programs. US \$284,000 would be utilised to propagate matters pertaining to training officials and obtaining advice with interactive workshops, seminars, recruitment etc. being organised to build capacity. Another US \$10,000 is to be spent on obtaining material, documents etc. Another US \$200,000 would be utilised to conduct awareness and educational programs (Ceylon Daily News 8 October 2008).

The existence of instruments of control (using documents and persons) involved does not in itself enhance the purpose of accountability as revealed by many respondents to this study. Rather, it depends to a greater extent on the attitude and involvement of members of Parliament (or political Power). Very often procedural changes are introduced with a view to enhancing the effectiveness of Parliamentary control over public spending, but the effectiveness of such procedures is subject to professional limitations of those involved in the whole process. Reservations and concerns are raised very often in professional and academic forums with regard to inadequacy of professionalism and lack of dynamic involvement coupled with deficient knowledge and awareness among those interacted with good governance and accountability issues and control aspects. We suggest that the theoretical frame that we used in this paper eventually explain the exact nature of the dynamics involved in the public financial management area in Sri Lanka.

Both oversight committees, as a device of Parliamentary control, face many criticisms due to the concerns of the stakeholders. As in the case of many reports tabled in the Parliament, the reports of the oversight committees are not debated in Parliament and most time it disappears without any notice. The reason, perhaps, is that most of the members of the Parliament are 
not interested in debating this because the accounts of three or four years back have been discussed, examined and enquired and placed before the Parliament (Warnapala,1997). Peter Keuneman $^{5}$, who served on the oversight committee for a period of 16 years, described the oversight committee (COPA) as an ornament in Parliament. He was of the view that it rarely discussed the policy questions, and the examinations conducted by the COPA were in the nature of post-mortems.

In the light of above findings, a few suggestions cold be made to improve the future summoning process of oversight committees in Sri Lanka. The public oversight committees have been described as the 'ultimate institutional judge' in the 'ex-post' process of assurance in parliament regularity, propriety and 'value for money.' They are fulfilling public expectations on pubic money as important guarantors of 'good governance'. It is clear from this empirical study that there should be a clear understanding of the ownership of certain institutions whether they are categorised under public or private entities. The members of Parliament (including Cabinet ministers) are to be summoned before the oversight committees during the investigations. It is apparent that a systematic record keeping mechanism ought to be introduced to track the past records associated with investigations of the oversight committees. The opposition party membership in the oversight committee ought to be increased for better transparency on matters relating to various investigations. Suitable penalties must be imposed or recommended for those who have misused or misappropriated public funding. It is true that in the recent past, the Secretary of the Ministry of Finance was held responsible and certain penalties were imposed on his misconduct on public funds. Similar actions must be taken for other public officers who have violated the financial regulations. Considerable delays have been observed in summoning persons and documents to committees. A corrective action should be taken to expedite this process. The Standing Orders associated with the COPA and the COPE appears to be outdated. There should be some clarity on the persons to be summoned before committees and revisions to Standing Orders are to be considered by the Parliament without further delay.

\section{Further Research}

There had been a civil war in Sri Lanka over the last three decades. The defence expenditure of the government on the war has been an important issue and various debates have been taken place during the past both nationally and internationally. As revealed in interviewees of this study the military persons, related expenditures and documents had never been summoned before oversight committees' examination in Sri Lanka. This issue has to be further investigated in a future study.

\section{References}

Alam Manzurul. (2006). Stakeholder theory in Zahirul. Hoque (ed) Methodological issues in accounting research. Theories, methods and issues, pp. 183-206. Spiramus Press:London.

Donaldson, T., \& Preston, L.E.(1995) The Stakeholder theory of the corporation: Concepts, evidence, and implications. Academy of Management Review, 20, 65-91.

\footnotetext{
${ }^{5}$ A former senior minister who served very important portfolios of the parliament of Sri Lanka
} 
Evan, W.M., \& Freeman, R.E. (1988) A Stakeholder theory of the Modern corporation: Kantian capitalism. In T.L Beauchamp \& N.Bowie ed. Ethical theory and Business, 75-84 Englewood Cliffs, NJ: Prentice-Hall.

Freeman, R.E., \& Evan, W.M. (1990) Corporate governance: A stakeholder interpretation. Journal of Behavioural Economics, 19, 337-359.

Freeman, R.E., (1984). Strategic management: A Stakeholder Approach. Boston: Pitman. http://dx.doi.org/10.1016/0090-5720(90)90022-Y

Hans J. Scholl. (2001). Applying Stakeholder theory to E-Governance benefits and Limits, FIP Conference Proceedings, 202.

Lisa, et al. (2005). The New Governance: Practices and Processes for Stakeholder and Citizen participation in the Work of Government Public Administration Review, 65(5), 547-558.

Loney, P. (2004), "Beware the Gap! - Parliamentary Oversight or Parliament Overlooked?” A paper for Association of Public Accounts Committees Conference, Nelspruit, South Africa.

Ludowyk, E.F.C. (1966). The Modern History of Ceylon, Weidenfeld and Nicolson, London, 158-65.

McGee, D. (2002). The Overseers: Public Accounts Committees and Public Spending, Pluto Press, London.

Meijer, I. S. M., M. P. Hekkert, et al. (2006). Perceived uncertainties regarding socio-technological transformation: towards a framework. International Journal of Foresight and Innovation Policy, 2(2), 214-240. http://dx.doi.org/10.1504/IJFIP.2006.009316

Mitchell, R.K. et al. (1997) Towards the Stakeholder Identification and Salience: Defining the principle of who and What Really Accounts. The management Review, 22(4), 853-886

Nage, J. (2000). The Emergence of the Public Sector Expectations Gap, International Conference on Accounting, Auditing and Management in Public Sector Reforms Zaragossa Spain, September,

Pakeman S.A. (1970). Ceylon Between Orient and Occident, Zeylanicus, Elek Books Limited London, pp.94-205.

Saward, M. (1996). Democracy and Competing Values. in Government and Opposition, Vol. 31(4), 467-486. http://dx.doi.org/10.1111/j.1477-7053.1996.tb01202.x

Scholl. et al. (2000). Accounting System Stakeholder Need Analysis. New York State Central. Albany, NY: Central for technology for Government.

Selznick, P. (1957). Leadership in Administration: A Sociological Interpretation. Berkeley, CA: University of California Press.

Silva, K. M. De. (1959). History of Ceylon, In Ray, H. C. (ed), University of Ceylon, Apothecaries' Company, Colombo. 
Tennert, J.R., \& Chroeder, A.D. (1999). Stakeholder analysis. Paper presented aat the $60^{\text {th }}$ Annual Meeting of the American Society for Public Administration, Orlando, FL.

The Ceylon Daily News. (2008). World Bank boosts from PAC and COPE, 08 October.

The Ceylon Daily News. (Sri Lanka), (2007). COPE: Parliament amend standing orders. Wednesday 22, August.

The Island (Sri Lanka). (2007). COPE Report - what next? By R.K.H.M. Fernando - Former Director General, Public Finance General, Treasury Department, 9 March.

The Parliament of Sri Lanka. (2007a). The Report of the Committee on Public Enterprises (COPE), Parliament Series No 07, Colombo, Sri Lanka.

The Parliament of Sri Lanka. (2007b). The Report of the Committee on Public Enterprises (COPE), Parliament Series No 10, Colombo, Sri Lanka.

Victoria, V. (2000). Report of the Public Accounts and Estimates Committee on Commercial in Confidence. Melbourne: Parliament of Victoria.

Warnapala, W.A.W., (2004), Parliament and Public Accountability in Sri Lanka - former Chairman, Public Accounts Committee of Parliament 1995-2000. Godage International Publishers (PVT) Ltd, Colombo, Sri Lanka.

Wehner, J. (2003). Principles and Patterns of Financial Scrutiny: Public Accounts Committees in the Commonwealth. Commonwealth and Comparative Politics, 41, 21-36. http://dx.doi.org/10.1080/14662040412331310181

Wijesekara, P. (2002). Parliamentary Practice in Sri Lank. Parliament Secretariat, Colombo, Sri Lanka.

World Bank. (2006). Report published by the Commonwealth Parliamentary Association, Parliamentary Financial Scrutiny; the role of Public Accounts Committees, August 